\title{
Mass Media, Interpersonal \\ Communication or Personal Experience?
}

\author{
Perceptions of Media Effects among Swedish Politicians
}

\author{
Bengt Johansson
}

Politicians and political parties commit ever-mounting resources to the pursuit of convincing and persuading citizens. Election campaigns are becoming increasingly professionalized, with deliberate strategies to win voters, and attempts to reduce uncertainty factors are becoming more and more sophisticated. Some researchers talk about an Americanization of election campaigns throughout the world, implying among other things that elections in different countries are becoming more similar to each other despite large differences in political culture, history and social institutions. Common features include the use of political advertising, the selection of candidates who play well on television, the use of political strategists, the production of campaign material by PR professionals, sky-rocketing campaign costs and the prominence of the mass media as the central campaign arena (see for example Negrine 1996, Nord \& Strömbäck 2003, Mancini \& Swanson 1997).

But how do politicians themselves see the process of opinion building? Are they certain that the mass media and political advertising are effective ways of convincing voters, or do they perhaps think that citizens' perceptions about politics are formed in other ways? These questions form the center of this article, which explores Swedish politicians' perceptions about the ways in which they and the general public formulate their political understandings.

\section{Perceptions about Media Power}

International research on opinions about media power has tended to focus on the views of citizens or the general public, although occasionally the desirability of studying elites is pointed out (Perloff 1996). While most of the research on views about media power is associated with the concept of third person effects, some of it exists as a subset of the study of general perceptions of public opinion formation (Entman \& Herbst 2000, Gunther \& Storey 2003, Gunther \& Christen 2001).

\section{The Persuasive Press Inference}

In opinion research, the tendency to exaggerate the effects of the media is referred to as the persuasive press inference (Gunther \& Christen 2001). It contains three primary 
aspects. The first comes from social psychology and is called the law of small numbers, which states that people tend to generalize about the effects of media content, however specific or atypical it may be (ibid). For example, if a person experiences a strong reaction to an article or news story, he or she is likely to assume that other people experience a similar reaction, thus generalizing the effects of the story, despite an everyday reality that might not exhibit evidence of the assumed effect.

The second factor is another form of generalization that could be called exposure generalization. This is the automatic assumption that the media have extensive reach and that the content that reaches oneself also reaches others (ibid). Of course, in a world where media consumption is increasingly differentiated, this is a highly doubtful assumption. Fewer and fewer people are sharing media experiences, and the portion taking part in exactly the same television-program on a given evening is steadily shrinking.

The third and final aspect is the tendency to exaggerate the power of mass media over people's thoughts (ibid). This is consistent with research on third person effects. The factors underlying third person effects will be taken up later, but it is worth noting that the media itself plays a role in shaping these views, not least by attributing causality to social phenomenon ranging from popular culture (video violence, rap music) to political journalism. Journalists themselves often see the media coverage of a political candidate as completely decisive to the outcome of the campaign, for example (Asp, 2003, Johansson 2001, Schudson 1995, Strömbäck 2001).

Despite these tendencies toward generalization, the research has also identified group and individual differences. One of the most influential factors appears to be the respondent's degree of personal involvement in the issue in question. An illustration of this is provided in Vallone et al's study, where they showed news stories on the conflict between Israelies and Palestinians to a group of people with strong sympathies for Israel, to a proPalestinian group and to a control group displaying sympathy toward neither group. The results showed that both groups with strong sympathies believed that the story would influence a neutral audience, though in different directions. Those sympathizing with Israel assumed the story would move opinion in a pro-Palestinian direction, while those sympathizing with the Palestinians believed that the audience would be influenced in a pro-Israeli direction. Those holding neutral views about the conflict did not believe that the story would influence audiences in any particular direction (Vallone et al. 1985). In other words, the more engaged a person is in an issue, the more they have something to loose by what they see as unfavorable media coverage. For a person who is not engaged in an issue, the role of the media matters much less, thus the tendency to exaggerate the effects of an individual story is greatly diminished.

The combined influence of issue involvement and exposure generalization further implies that groups particularly interested in politics will be likely to assume that other groups in society will be highly influenced by political news coverage. Michael Schudson has illustrated this in the case of American journalists' self-image (Schudson 1995), and other studies have shown that Swedish journalists as a group ascribe more power to the media than does the general public (Johansson 2003a). Similarly, then, it is likely that politicians will be more likely than others to assume that the media exerts a strong influence in the formation of political public opinion.

A somewhat different explanatory perspective can be found in French sociologist Pierre Bourdieu's concept of the structure and legitimation of social fields. A social field arises when people compete over shared symbolic and material resources. The players in a field share certain traits, specific investments are required of new entrants, specific 
inputs must be put into the game, there are specific gains to be made, and most importantly, all participants share a certain risk - something is at stake. Fundamental to social fields is the existence of shared beliefs that legitimize the field both internally among players and externally among society members (Bourdieu 1984; Broady 1988). Within the social field of political communication, the notion of strong media effects is one such shared belief held by the various players in the field (politicians, PR consultants and journalists). It should be noted that, although these perceptions are not necessarily false, they do carry the risk of exaggerating media influence.

Rather than competing with each other, these theories can be seen as operating in tandem. If politicians, journalists and others within the political communication field believe more in the power of the media than others, this can be seen as an expression of the fact that within the field there is a greater occurrence of shared perceptions about media power. This in itself can be seen as a form of involvement - that one's own activity is given more weight.

\section{First and Third Person Effects}

Third person effects imply that other people are more influenced by media messages than one self. The phenomenon has been researched for 20 years by opinion researchers and there is no doubt that the phenomenon exists. Numerous studies show that people generally assume that other people are more influenced by the mass media than they themselves are. Studies on the third person effect seek to identify the circumstances under which the phenomenon arises and what the behavioral consequences might be. While no direct studies of people's actual behavior has been conducted, several studies have found third person effects in connection with opinions on censorship and freedom of expression issues. In general, strong support for the perceptual component of the theory has been demonstrated but only limited support exists for the behavioral component (Johansson, 2002, Neuwirth et al 2002).

Studies have also identified reversed third person effects, or first person effects, as they are also known. This means that the individual assumes that they are affected more than other people. Whereas third person effects tend mainly to be associated with socially unacceptable media messages (violence, pornography, etc.), first person effects tend to be linked with socially acceptable and desirable messages - when being influenced by media is associated with intelligence, for instance (Johansson 2000, Perloff 1993, Perloff 1996).

Explanations for such distinctions between the self and others can easily be sought in the classical communication chain - sender, channel, message and receiver. The most central explanatory notion behind such distinctions is that of self-enhancement, or the desire to maintain a positive self-image (Duck \& Mullin 1995). The research displays clear third person effects in relation to media with low credibility (sensational, tabloid press) and first person effects in relation to high status media. People who see themselves as experts in one way or another (highly educated, experienced, knowledgeable) also tend to make greater distinctions than those who don't. Generally, the operating principle is that a person tends to see him/herself as less vulnerable to media messages than are other people. There is a paternalistic strain here, whereby one does not see oneself as an "ordinary person". Ordinary people are more gullible and malleable than one self. Issue involvement can also be connected to third person effects. The example with the experiment mentioned above showed that greater involvement can lead one to jump to conclu- 
sions and believe the worst about media messages that contradict one's own interests (Johansson 2002).

\section{Politicians and the Power of Mass Media}

Research has been conducted on politicians' perceptions about the media's public opinion building effects. However, whether addressing specific issues or general opinion processes, questions about media effects tend to be peripheral. There seems to be an absence of studies whose central research question concerns perceptions among actors in the political communication field about the influential power of the media.

Perhaps the study that comes closest to examining such questions is Susan Herbst's study of politicians, journalists and activists' views about the media and public opinion, although here the focus rests on the concept of "public opinion" rather than media effects per se (Herbst 1998). Within Nordic research there are some general overviews of party organizations, parliamentarian and municipal politicans' beliefs about the power of the mass media (Esaiasson 1990, Hardarson 2000, Holmberg \& Esaiasson 1988, Johansson 1995, Pierre \& Djerf 1991). The question of politicians' views about media influence is also addressed in a few case studies (Johansson 2003b, Larsson 1998, Wrenne 1998).

What do the results of these studies show? The research based on interviews and observations suggest that decision-makers often see the media image as a direct reflection of general opinion (Herbst 1998). Other studies show that while politicians sometimes do not see the media as a direct reflection of opinion today, they see it as a barometer of opinion, i.e. of where opinion will be tomorrow, thus it serves as strategic consideration in decision-making (Anthonsen 2003). Studies also show that political elites believe that media images exert a nearly unlimited influence on audience opinion and behaviors (Johansson 2003b, Wrenne 1998). This is not to say that the media's image is always central. Studies of decision-makers in foreign affairs issues show that media coverage is not a primary consideration (Anthonsen 2003). However, other research shows the opposite. A study of how the press affects federal policymaking, shows that politician's perceptions of the connection between the media image and general opinion influenced the decision not to dispatch the neutron bomb in the end of the 1970's (Linsky 1986, see also Schudson 1995). Generally speaking, the media picture tends to be ascribed more power and influence as a factor in decision-making in policy arenas where decision-makers are more directly influenced by support in the voting arena (Johansson 2003b).

More general overviews display the same tendency. The media is assumed to exert great power to influence both politics and opinion. When politicians rank order the social institutions that have power and those that ought to have power, the results show that the mass media is seen as having great power - not least over the political agenda. However, although the media is seen as exerting great influence, there is unity in the view that this power is too extensive. The media are seen as possessing more power than they ought to have (Hardarson 2000, Pierre \& Djerf 1991).

One of the gaps in the research on perceptions of media effects generally and third person effects in particular is the study of elite groups. Such a focus seems particularly relevant, however, both in terms of potential policy decisions that pertain to mass media (such as advertising, censorship) and in terms of the future development of political election campaigns in an increasingly mass-mediated society.

The purpose of this article, therefore, is to examine politicians' perceptions of the opinion building power of the mass media compared to other information channels. The 
analysis also explores differences among politicians and differences between the politician group as a whole relative to the responses of the general population.

There are two main research questions. The first is: What importance do politicians assign to various information channels in terms of their relative influence on general public perceptions about politics? The results are compared to responses to the same question by members of the general public, thus making it possible to determine whether politicians assess information channels differently than ordinary citizens. Differences between politicians are also explored in order to determine whether different backgrounds or experience can explain eventual variations within the politician respondent group.

The second question explores the degree of first and third person effects among politicians. As is the case with the first question, the results are compared to the responses of ordinary citizens and differences between politicians are also explored in an attempt to identify possible factors that might explain the ways in which politicians distinguish themselves from others in terms of media influence.

\section{The Setting}

Sweden has been a parliamentary democracy for many years. While the constitutional basis for the representative democracy is stable, the legal and political settings have changed in certain notable respects since the 1950 s, reflecting a growing political complexity that falls into the general patterns of modernization. These include an increasingly fluid voter base, more professionalized political parties and the increasing prominence of the media as the primary political arena (Asp \& Esaiasson 1996).

Recent decades have witnessed important changes in the political system in Sweden. Membership in the EU has introduced a supranational level of politics, while within Sweden new forms of regionalism have been established (Sjölin \& Jerneck 2000). The electoral system has also undergone important changes, the most significant being the introduction of personalised voting whereby alongside voting for a political party, voters can also select individual candidates (Holmberg \& Möller 1999).

Contact between voters and elected officials occur mainly through the mass media both during and between election campaigns. Opinion building occurs mainly via the news and other public affairs programs. Because political advertising is not allowed on public service television and radio or on the terrestrial commercial channel TV4, the significance of political advertising is not as great as in other western countries. The primary channels for political advertising are therefore newspapers, billboards, the cinema and to some extent commercial radio. Among the political parties, however, political advertising is not seen as particularly important. News coverage and interpersonal communication are seen as more effective channels of communication (Esaiasson, 1990; Nord \& Strömbäck, 2003).

If we look at media use, Sweden is known to be among the world's top five in Internet use. But at the same time, newspaper readership is also strong. More than 80 percent of the adult population read a newspaper on an average day. This also puts Sweden on the top five list in newspaper reading in the world. It is worth mentioning that almost all newspaper are local or regional - only two tabloid newspapers and one business paper can be regarded as national. The local morning paper and national television are the main media for an average Swede (Weibull, 2001).

Sweden's national television system is based on a tradition of public service broadcasting without commercials. In 1986 the first commercial satellite and cable-channels 
started to challenge this system, and in 1991 it was decided that a new terrestrial commercial television channel would be established. In the beginning of the new century, the television market is dominated by the two public service channels (SVT1, SVT2) and the commercial channel (TV4). Of the total audience market, these channels have more than 70 percent. In radio, the public service Company (SR) is the dominating actor. On the commercial side, four networks with national ambitions have emerged. The radio market is currently under pressure, since the private stations have not attracted large audiences (ibid).

\section{Method}

The politicians examined in this study are elected officials in Region Västra Götaland of Sweden, which encompasses 1.5 million of Sweden's 9 million inhabitants. This county was created in 1999 from the convergence of three prior county councils and the city of Göteborg's decision-making functions concerned with healthcare. The main responsibility of the regional authority is health care, which constitutes 90 percent of the budget. Other administrative areas are regional development and culture. The analysis of politicians is based on a survey sent to all elected officials within the Region Västra Götaland during the fall of 2001. In order to compare the politician's views of the media's power with the views of the general public, a portion of the national SOM-study (Society-Opinion-Media), taken at the same time, was included in the analysis.

In the surveys, two identical sets of questions were presented. In the first, respondents were asked to judge how they think their own perceptions of politics are formed. In the second, they were asked to make similar judgements about the general public or "ordinary Swedes". The information channels they were asked to judge were personal experience, interpersonal communication, television, newspapers and political advertising (for more information on sampling, survey question formulation and comments on variables, see Appendix).

\section{How are Political Perceptions among the Public Formed?}

The first research question asks whether politicians and citizens differ in the way they judge the influence of various information channels. Following the theoretical overview conducted above, a logical hypothesis might be that politicians would be more likely to ascribe greater power to the media. Politicians are part of the political communication field and are dependent upon the media to communicate with voters and receive information on issues and other political actors' behavior. This dependence, combined with the uncertainty stemming from a lack of control over the media image itself, stimulates involvement. Given the present setting, in which the more traditional party-based press is becoming more professionalized (i.e.non-partisan) and commercialized, a political actor is not likely to expect loyalty from the mass media.

The results in Table 1 show that, with the exception of political advertising, all of the opinion channels are seen as important by both politicians and citizens. The mean values of personal experience, interpersonal communication, television and newspapers exceeds 2.5 , which implies that a majority view the channels as either a very important or fairly important influence on people's political perceptions. 
Table 1. Politicians' and Ordinary Citizens' Judgments about the Influence of Various Information Channels on Political Perceptions of the General Public (mean scores)

\begin{tabular}{lccccc} 
& Politicians & Citizens & $\mathrm{N}$ & $\mathrm{t}$ & sig. \\
\hline Personal experience & 3,08 & 3.00 & $477 / 277$ & 1,55 & $\mathrm{p}<.122$ \\
Interpersonal communication & 3,19 & 2.97 & $480 / 273$ & 4,32 & $\mathrm{p}<.000$ \\
Television & 3,32 & 2,95 & $479 / 275$ & 7,16 & $\mathrm{p}<.000$ \\
Newspapers & 3,17 & 2,80 & $477 / 274$ & 7,18 & $\mathrm{p}<.000$ \\
Political advertising & 2,22 & 2,20 & $476 / 274$ & 0,34 & $\mathrm{p}<.737$ \\
\hline
\end{tabular}

Note: The scale contains four values ( $4=$ very important; $3=$ fairly important; $2=$ not especially important; $1=$ not at all important). The closer to 4 , the more important the channel is judged to be.

Politicians and citizens do not differ in their judgments about personal experience and political advertising. Here, the views of politicians and the general public resemble one another. However, it is clear that politicians are more likely to ascribe greater power to the remaining three channels (television, newspapers and interpersonal communication) than are ordinary citizens. The greatest difference between politicians and citizens lies in their views about the power of television and newspapers.

Another interesting question is whether politicians and citizens rank order the information channels in similar ways. To determine whether the differences in the rank ordering are significant, a paired t-test is used. The differences noted are all significant. For more information about the test, see Appendix. Looking at the implicit rank ordering, politicians seem to rank television as the most important opinion-building channel followed by interpersonal communication and newspapers. Personal experience is seen as somewhat less important, even though a clear majority (76 percent) expresses the view that personal experience plays a very important or fairly important role in generating political views among the general public. Political advertising is, as already mentioned, the channel ascribed the least opinion-building power. This should not be interpreted as meaning that political advertising is seen as having no effect, but rather more as an expression of the view that political advertising is, despite everything, still a marginal phenomenon in Swedish political culture. Research has shown that people's views about the influence of media messages also depends on their assumptions about how many other people are exposed to the content (McLeod et al 1997). This can be connected to the theory of exposure generalization - one does not ascribe political advertising much weight if one believes that other people are not exposed to it.

The views of the general public are not exactly the same as those of politicians. For example, they do not rank television as the most influential information channel. Rather, they give roughly equal weight to personal experience, interpersonal communication and television. By contrast, newspapers are seen as less central, and, as is the case with politicians, political advertising is seen as the least influential.

What about the politicians as a group? Do they display any notable differences, or are they fairly homogenous? One way to compare politicians' responses is to group them according to their degree of political involvement. Two methods are applied here. The first is to see whether 'full-time' politicians (regional or municipal council members) have a different view than those whom are not employed full time in a political position. The second method is to see whether the number of political appointments or positions one occupies (i.e. committee memberships) can be related to views about the relative 
weights of various information channels. For simplicity and ease of presentation, the first variable is called 'job type' and the second variable is referred to as 'experience'.

Education levels vary among politicians. Barely ten percent report that they have only a primary school education. About one third have completed secondary school and more than half have received some form of higher education. This means that it is possible to examine whether politicians with different educational backgrounds make the same judgments about opinion building and information channels.

Gender and age are additional demographic variables that seem relevant in terms of possible differentiations among politicians in their evaluations of information channels.

Table 2. Politicians' Views on Influence of Various Information Channels in Shaping General Public Perceptions of Politics in Relation to Personal Experience, Social Environment, Television, Newspapers and Political Advertising (standardized regression coefficients)

\begin{tabular}{lccccc} 
& $\begin{array}{c}\text { Personal } \\
\text { experience }\end{array}$ & $\begin{array}{c}\text { Interpersonal } \\
\text { communication }\end{array}$ & Television & Newspapers & $\begin{array}{c}\text { Political } \\
\text { advertising }\end{array}$ \\
\hline Age &, 03 &,- 04 &, 00 &, 01 &, 06 \\
Gender &, $17^{* * *}$ &, 05 &, 05 &, 10 &, 07 \\
Education &, $13^{* * *}$ &, $14^{* * *}$ &, $10^{* *}$ &, $10^{* *}$ &,- 08 \\
Job type &,- 01 &, $09^{*}$ &, $11^{* *}$ &, $09^{* *}$ &,- 06 \\
Experience &, 04 &, 07 &,- 01 &, $04 *$ &,$- 11^{* *}$ \\
$\mathrm{~N}$ & 465 & 468 & 467 & 465 & 464 \\
$\mathrm{R}^{2}$ & $5 \%$ & $4 \%$ & $2 \%$ & $3 \%$ & $1 \%$ \\
\hline
\end{tabular}

Note: $*=\mathrm{p}<.10, * *=\mathrm{p}<.05, * * *=\mathrm{p}<.01$

On the whole, the demographic factor appearing to exert the greatest influence on politicians' assessments is education (Table 2). ${ }^{1}$ The higher education one has, the more likely one is to believe that all channels other than political advertising affect the political views of the general public. Job type also seems to correlate with judgments about interpersonal communication, television and newspapers. The more full-time one's political activity, the more likely one is to ascribe influence to these channels. Political experience seems to matter in two cases. First, those with numerous appointments see newspapers as more influential, and second, they are more likely to minimize the influence of political advertising compared to other politicians. Gender only appears to exert influence in views about personal experience. Women appear somewhat more likely than men to believe that general political attitudes are formed by personal experience. Finally, the table shows that age does not account for any difference in viewpoint among politicians. ${ }^{2}$

The results of the comparison between politicians and the general public have shown that politicians and the general public exhibit fundamental differences in their assessments of information channels. Although politicians generally assign greater weight to all information channels (except political advertising) than does the citizens, the central point is that whereas politicians see television, newspapers and interpersonal communication as more influential than personal experience, the citizens does not make this distinction. Furthermore, politicians assign more weight to newspapers than does the citizens.

Within the politician group, the data suggest that education and political involvement play some role in explaining differences. Interestingly, politicians do not differ in the way 
they rank order these items. Even those with less education and less involvement, for example, place television at the top of the list.

The next question is how politicians view themselves compared to the citizens in terms of political opinion building. Do they think that they are influenced in the same way as the general public, or do they differentiate themselves from ordinary citizens?

\section{Politicians and Third Person Effects}

The above section compared the assessments of politicians to those of the citizens and observed that politicians ascribe more power to the media and other information channels than does the citizens. In this section, attention shifts to first and third person effects. How do politicians see the forces that shape their own perceptions of politics? Do they assign the media a strong role in shaping their own views about politics, for example?

Table 3. Politicians' Views on the Influence of Various Information Channels in Shaping their Own and General Public's Perceptions of Politics (mean score)

\begin{tabular}{lcccccc} 
Politicians & $\begin{array}{c}\text { Influence } \\
\text { on self }\end{array}$ & $\begin{array}{c}\text { Influence } \\
\text { on others }\end{array}$ & $\begin{array}{c}\text { Person } \\
\text { effect }\end{array}$ & t & sig. & $\mathrm{N}$ \\
\hline $\begin{array}{l}\text { Personal experience } \\
\text { Interpersonal }\end{array}$ & 3,65 & 3,08 & $-0,57$ & $-14,10$ & $\mathrm{p}<.000$ & 476 \\
communication & 2,85 & 3,19 & 0,34 & 8,50 & $\mathrm{p}<.000$ & 467 \\
Television & 2,44 & 3,32 & 0,88 & 21,24 & $\mathrm{p}<.000$ & 475 \\
Newspapers & 2,48 & 3,17 & 0,69 & 16,65 & $\mathrm{p}<.000$ & 472 \\
Political advertising & 1,80 & 2,20 & 0,40 & 11,33 & $\mathrm{p}<.000$ & 473 \\
\hline
\end{tabular}

Note: $* * *=\mathrm{p}<.01, * *=\mathrm{p}<.05, *=\mathrm{p}<.10$.

Table 3 shows that politicians systematically distinguish themselves from the general public. There is a strong third person effect among politicians. In their eyes, television and newspapers are the channels that exert the most influence over the general public relative to themselves. However, political advertising and conversations with others are seen as being more influential on ordinary citizens than on politicians themselves.

Views about personal experience are the direct opposite. Here one sees evidence of a first person effect. The perception among politicians is thus that they see themselves as more influenced than the general public by personal experience.

The presence of a first person effect in connection with personal experience and third person effects for other information channels supports theories concerning the tendency people have to distinguish between themselves and others in order to maintain a positive self-image. Being influenced by other people, by the mass media, and especially by advertising suggests that one is not in control, that one can be manipulated and make unconscious choices. It is therefore quite reasonable that third person effects appear in connection with different forms of communication. The appearance of first person effects can be explained in the same way. Personal experience can be seen as the ideal form of political opinion building. If one's own perceptions of politics are formed by the experiences one has, this indicates a larger degree of independence and intellectual capacity. 
In general, the data shown thus far point to a tendency among politicians to cultivate what might be termed an autonomous political self-image, meaning that while ordinary people are influenced by the mass media and the social environment, they themselves derive their political perceptions mainly from their personal experiences.

Table 4. Citizen's Views on the Influence of Various Information Channels in Shaping their Own and General Public's Perceptions of Politics (mean score)

\begin{tabular}{lcccccc} 
General public & $\begin{array}{l}\text { Influence } \\
\text { on self }\end{array}$ & $\begin{array}{l}\text { Influence } \\
\text { on others (mean difference) }\end{array}$ & diff & sig. & $\mathrm{N}$ \\
\hline $\begin{array}{l}\text { Personal experience } \\
\begin{array}{l}\text { Interpersonal } \\
\text { communication }\end{array}\end{array}$ & 3,05 & 3,00 & $-0,05$ & $-1,53$ & $\mathrm{P}<.127$ & 276 \\
Television & 2,52 & 2,97 & 0,45 & 9,23 & $\mathrm{P}<.000$ & 272 \\
Newspapers & 2,64 & 2,95 & 0,31 & 6,67 & $\mathrm{P}<.000$ & 272 \\
Political advertising & 2,54 & 2,80 & 0,26 & 5,52 & $\mathrm{P}<.000$ & 274 \\
\hline
\end{tabular}

Note: $* * *=\mathrm{p}<.01, * *=\mathrm{p}<.05, *=\mathrm{p}<.10$.

Looking now at the citizens responses to these questions (Table 4), it appears that they do not see themselves as very different from others in terms of being influenced by television and newspapers. Third person effects for television and newspapers do appear among the citizens, but they are not as dramatic as those displayed by politicians. Instead, the greatest distinctions made by members of the general public are in terms of interpersonal communication and political advertising, both of which they see as exerting more influence on others than on themselves.

In contrast to politicians, members of the general public do not see themselves as more influenced than others by personal experience. However, a disaggregated analysis of the group reveals the presence of two opposite views within the general public concerning the role of personal experience in opinion building. Higher resource groups - those with a high education and those with a great deal of political interest - tend to resemble politicians in the sense that they see personal experience as more important for them than for others, who they see as more influenced by other forms of communication (interpersonal communication, television or political advertising). It should be mentioned, however, that these high resource groups do not display the levels of first and third person effects found among politicians (see Johansson 2002).

Views about the influence of newspapers differ among groups within the general public. Here, a significant first person effect exists among politically involved and highly educated people. This is most likely to be an indication that these groups consider it prestigious to be influenced by the political news of the daily press.

Among low resource groups, the pattern is essentially the opposite. Here, a person is more likely to assume that that he or she is more influenced by other people, by the media, and more by television and advertising than is the case for high resource groups. Furthermore, lower resources groups are also more likely to assume that the prestige media and personal experience exert more influence on other people than they do on themselves. In this sense, then, these groups display a view of political opinion building that could be described as a dependent political self-image, where interpersonal commu- 
nication and the less prestigious media play a larger role in their own political understandings (ibid).

The question remains as to whether there are differences within the politician group. Table 5 looks at the influence of independent factors on the appearance of first and third person effects. The factors included in the model are the demographic variables of age and gender as well as length of residence, education and job type. The reason for incorporating the number of years of residence is that this serves as an indicator of how socially integrated one is into the local community (see Johansson 1998, Janowitz 1952). This, in turn, can be seen as influencing one's views about information channels. The reason for excluding political authority from the model is that it tends to covary with job type, thus the inclusion of both tends to weaken the explanatory power of the model. ${ }^{3}$ Also included in the model is a control variable known in the third person effects literature as second person effects (Neuwirth et al 2002). This variable takes into account the degree of influence the media has both on one self and others and therefore allows for a certain 'levelling' of the influence of the media often missing in third person effects studies. For example, those who believe that different information channels have great influence on both the self and on others receive a higher value than those who believe that the media influences neither themselves nor other people. Purely technically, the variable is an additive index of the questions on the degree to which one self and others are influenced by various information channels (see Appendix).

Table 5. First and Third Person Effects among Politicians in Relation to Personal Experience, Social Environment, Television, Newspapers and Political Advertising (standardized regression coefficients)

\begin{tabular}{lccccc} 
& $\begin{array}{c}\text { Personal } \\
\text { experience }\end{array}$ & $\begin{array}{c}\text { Interpersonal } \\
\text { communication }\end{array}$ & Television & Newspapers & $\begin{array}{c}\text { Political } \\
\text { advertising }\end{array}$ \\
\hline Age & 0,01 & $-0,01$ & $-0,02$ & $-0,05$ & 0,04 \\
Gender & 0,07 & $-0,02$ & $-0,03$ & 0,04 & 0,01 \\
Length of residence & 0,02 & $-0,11^{* *}$ & $-0,06$ & 0,03 & 0,00 \\
Education & $0,08^{*}$ & 0,07 & 0,07 & 0,02 & 0,08 \\
Job type & $-0,08^{*}$ & 0,04 & $0,08^{*}$ & $0,09 *$ & $-0,02$ \\
2nd person effect & $0,33 * *$ & $0,19 * *$ & $0,15^{* * *}$ & $0,10^{* *}$ & 0,06 \\
\hline $\mathrm{N}$ & 464 & 455 & 463 & 460 & 461 \\
$\mathrm{R}^{2}$ & $14 \%$ & $5 \%$ & $4 \%$ & $2 \%$ & $1 \%$ \\
\hline
\end{tabular}

Note: $* * *=\mathrm{p}<.01, * *=\mathrm{p}<.05, *=\mathrm{p}<.10$.

Relatively few of the explanatory factors included in the model can explain the differences, although job type seems to play a role. The more full-time a person's political job is, the more likely he or she is to distinguish between him/herself and the general public in seeing the latter as more influenced by television and newspapers and the former as more influenced by personal experience. In other words, the more full-time one's political position, the more autonomous one's political self-image, which suggests that increased involvement strengthens this view of political opinion building.

Somewhat surprisingly, education displays a significant third person effect with personal experience. Previous research has shown that education is an important explanatory factor as to why one distinguishes between oneself and others. In light of the above 
discussion, education might be expected to correlate with first person effects rather than third person effects, i.e. the higher one's education, the more likely one would be to see personal experience as an more influential for oneself than for others. However, the results show that highly educated politicians assume that other people are more influenced by personal experience than they themselves are, a pattern that is the opposite of that exhibited among the citizen group (Johansson 2002). In other words, education appears to operate differently among politicians than it does among the general public in terms of assessments about the role of personal experience.

One's length of residence in the community seems to explain the appearance of first person effects in judgments about the role of interpersonal communication. It is likely that the longer one has lived somewhere, the more likely they are to have built up a social network, which in turn could lead to placing more weight on the influence of people in one's surroundings.

Clearly, however, the strongest explanatory variable in the model is the second person effect, or the level of imagined influenced of the various channels on the self and others. The result show that second person effects are a strong contributing factor to both first and third person effects. The strongest connection is between first person effects and personal experience. This variable also shows itself to be significant in terms of third person effects for interpersonal communication, television and newspapers. General faith in the influence of personal experience is thus an important explanation of one's belief that others are also more influenced by personal experience. For the other information channels, however, the relationship is the opposite. In terms of interpersonal communication, television and newspapers, people tend to assume that they are more influenced than others - a first person effect - the higher one's index score.

To summarize the analysis of third person effects, the data suggest that such effects exist and they are more extensive among politicians compared to the citizens. Politicians not only believe more in the power of the media to influence people's political understandings, but they also assume that other people differ considerably from themselves in the ways in which such understandings are shaped. Therefore they have, perhaps not unexpectedly, a rather different view of political opinion building than ordinary citizens. In the politicians' worldview, they themselves are most influenced by their own experience, while other people are more influenced by the other forms of communication. The greatest difference, according to them, is the influence of television and newspapers. Even interpersonal communication and political advertising are seen as influencing the general public much more than themselves. In this sense, politicians differ from the judgments of ordinary citizens. Of course, both first and third person effects exist among citizens as well, though not to the same extent. There are also certain differences between politicians. In general, the more weight politicians assign to the media and other information channels, the greater their tendency to distinguish themselves from others. A politician's educational background and degree of political involvement also seems to play a role in shaping perceptions.

\section{Conclusions}

The purpose of this article has been to examine politicians' views about the opinion building power of the media compared to other channels of information. The results have shown that politicians see the media as more influential than other forms of information dissemination. It has also been clearly shown that politicians assign more importance to 
the media than do citizens generally. Furthermore, politicians are more likely to believe that their own political views are shaped in quite different ways than those of the general public. While they believe themselves to be primarily influenced by their own personal experience, they believe members of the public to be mainly influenced by the mass media and other people in their surroundings. There were also differences between politicians. Factors identified as distinctive in other research, such as education and political involvement, have received further support here. In this study, for example, at the aggregate level, politicians as a group distinguish themselves from ordinary citizens in terms of ways in which political views are shaped. Within the politician group, this distinction correlates positively with higher degrees of political involvement.

How should the differences between politicians and citizens be explained, and what are their potential consequences? In terms of views about the media's power and the distinction politicians make between themselves and the general public, it is of course quite possible that the politicians are simply correct. Perhaps it is true that television and newspapers are the primary molders of political views among the general public, with their own personal experience being less influential. Furthermore, it is perfectly logical that politicians will generate their perceptions of politics through their direct personal experience, because their direct personal experience is more directly connected to political decision-making than is the personal experience of members of the general public. This could perhaps explain why first and third person effects are greater among politicians. However, it does not explain why politicians see the general public as more influenced by television and newspapers than does ordinary citizens. And the fact that this perception is even more pronounced among politicians with more education and greater degrees of involvement reduces the belief that it reflects actual knowledge about opinion building mechanisms ${ }^{4}$

It is at this point that Bourdieu's concept of a social field might be reintroduced. Politicians are part of the political communication sphere, where belief in the mass media is a fundamental tenet. Politicians are also large consumers of mass media and have a great interest in politics. They therefore assume that people generally are more exposed to the media than they actually are. With their greater degree of involvement, they further assume that the general public is more affected by news about politics than ordinary people judge themselves to be. Citizens are less interested than politicians in politics are, and they are less interested in consuming political news. Therefore, they are not as likely to exhibit the kind of exposure generalization tendencies that one finds among politicians. And because ordinary citizens consume less political news and are less politically involved, they also see media exposure as less influential.

What are the consequences of these opinion-building perceptions? Perhaps most importantly, politicians' relatively fundamental views about the influence of television and newspapers imply that they are likely to increase their concentration on the mass media. In the worldview of the politician, television and newspapers are the most effective way to build opinion. Thus one of the central actors in the political communication field seems to be confirming the notion that the mass media's role in modern political campaigns will intensify. As long as politicians themselves believe in the media's power over peoples' thoughts, campaigns are likely to be more media-centric. As a result, it is also likely that politicians will try to be more of a 'co-player' to the mass media, applying all their tools to attract journalistic interest. Even if there are many critics of media-centric opinion building, the notion of medialized politics appears in any case not to be disputed or threatened by politicians themselves. 


\section{Notes}

1. The explained variance $(R)$ that measures how much of the variation in the dependent variable can be explained with help of the independent variables included in the model is quite low throughout. The factors used in the model have relatively low explanatory power to explain differences between the viewpoints of the various politicians. In part this is because of the fact that there are not any great differences to explain and that the differences that exist are more explained by other factors not included in the model. Neuwirth et al (2002) means that studies of person effects ought to be conducted in terms of concrete issues rather than in terms of general views about media effects. This is because it would be more apparent how the mechanisms for potential effects work. It is possible that the criticism can also be applied to the design of this study.

2. It should be pointed out that the variance in the age variable is relatively small in the politician group. Most are middle-aged (43 percent between 50 and 59 and only eight percent younger than 39).

3. This is an example of multicollinearity, which is a problem within regression analysis when independent variables covary and reduce explanatory power from each other. Multicollineariety can result from insufficient data. With a larger sample the problem could be reduced. However, it is also possible that the variables measure the same thing, in which case the most appropriate step is to eliminate one variable. In the regression model in this paper, the issue is likely to be overlapping variables. Full-time politicians also tend to have a number of political appointments, thus the variable of political experience was eliminated because it lowered the explanatory power of the model.

4. One central question that is not addressed earlier is the possibility that exists to generalize the results appearing here. Regional politicians, who are most often also municipal politicians, can most likely be seen as representing other local politicians in Sweden. There is nothing that suggests that politicians in Region Västra Götaland should differ from other regional and municipal politicians.

However it is not apparent that the results would be the same if national politicians were studied. Of course it cannot be stated with certainty, but support for the notion that the results might not have been completely different if national politicians had been included comes in the form of a study of Swedish parliamentarians (Johansson 1995). The tendencies toward greater faith in television's opinionbuilding power and that politicians with more experience and higher education also showed themselves in this study agree with the analysis of parliamentarians. Even if one cannot be certain there is at least nothing that directly points to the possibility that national politicians would differ from regional and municipal politicians in terms of their views of media power.

Translation: Susan Holmberg

\section{References}

Anthonsen, Mette (2003) Decisions on Participation in UN Operations: Do Media Matter? Danish and Swedish Response to Intra State Conflicts in the 1990s. Göteborg University: Department of Political Science.

Asp, Kent \& Esaiasson, Peter (1996) The Modernization of Swedish Campaigns: Individualization, Professionalization, and Medialization, in Swanson, David L. \& Paolo Mancini (ed.) Politics, Media and Modern Democracy. Westport, CT: Praeger Press.

Asp, Kent (2003) Medieval 2002. Partiskheten och valutgången. Göteborg: Göteborgs universitet, JMG:

Bourdieu, Pierre (1984) Distinctions. London: Routledge.

Broady, Donald (1988) Kulturens fält. Om Pierre Bourdieus sociologi, in Masskommunikation och kultur, Nordicom-Nytt/Sverige 1-2.

Duck, Julie. M., \& Mullin, Barbara A. (1995) The Perceived Impact of the Mass Media: Reconsidering the Third-Person Effect. European Journal of Social Psychology 25, 77-93.

Entman, Robert M \& Susan Herbst (2000) "Reframing Public Opinion as We Have Known It", in Bennet, W. Lance \& Robert M. Entman: Mediated Politics. Communication in the Future of Democracy. Cambridge: Cambridge University Press.

Esaiasson, Peter (1990) Svenska valkampanjer 1866-1988. Stockholm: Publica.

Eveland Jr, William. P.; Nathanson, A1; Detenber, Benjamin H.; \& Douglas M. McLeod (1999) Rethinking the Social Distance Corollary. Perceived Likelihood of Exposure and the Third-Person Perception. Communication Research 26, 275-302. 
Gunther, Albert C. \& Cindy T. Christen (2001) Effects of News Slant and Base Rate Information on Percieved Public Opinion". Journalism and Mass Communication Quarterly, Vol. 76:277-292.

Gunther, Albert C. \& J. Douglas Storey (2003) The Influence of Presumed Influence, Journal of Communication 2003 53: 199-215.

Hardarson, Ólafur Th (2000) "Might and Right: Views of Power in Society, in Esaiasson, Peter \& Knut Heidar (ed) Beyond Westminister and Congress. The Nordic Experince. Columbus : Ohio State University Press.

Herbst, Susan (1998) Reading Public Opinion. How Political Actors View the Democratic Process. Chicago: The University of Chicago Press.

Holmberg, Sören \& Peter Esaiasson (1988) De folkvalda. En bok om riksdagsledamöterna och den representativa demokratin i Sverige. Stockholm: Bonnier.

Holmberg, Sören \& Tommy Möller (1999) Premiär för personval’. SOU 1999:92.

Janowitz, Morris (1952) The Community Press in an Urban Setting. Chicago: The University of Chicago Press.

Jerneck, Magnus \& Mats Sjölin (2000) Regionalisering och flernivådemokrati - Skåne och Kalmar län. Lunds universitet: Statsvetenskapliga institutionen.

Johansson, Bengt (1998) Nyheter mitt ibland oss. Kommunala nyheter, personlig erfarenhet och lokal opinionsbildning. Göteborg: Göteborgs universitet, JMG.

Johansson, Bengt (2000) Tredjepersonseffekter och politisk kommunikation, Nordicom-Information 2000:2.

Johansson, Bengt (2001) När opinionen ska förklaras. Förklaringar till valutgång och väljaropinion $i$ svensk dagspress under valrörelsen 1998, DMI-rapport 21. Sundsvall: Demokratiinstitutet.

Johansson, Bengt (2002) Images of Media Power: the Third-Person Effect and the shaping of Political Attitudes. Paper presented at the 23 Conference and General Assembly IAMCR/AIECS/AIERI International Association for Media and Communication Research Barcelona, 21-26 of July 2002, the Political Communication Section.

Johansson, Bengt (2003a) Journalisterna och mediernas makt: föreställningar om mediernas påverkan inom politisk kommunikation. Sundsvall: Demokratiinstitutet.

Johansson, Bengt (2003b) "Pengafusket i regionen". En analys av politikers beslutsfattande under en mediegranskning. Göteborgs universitet: Utvärderingsprogrammet: Västra Götalandsregionen: Rapport 16.

Johansson, Folke (1995) Riksdagen och massmedia. Göteborgs universitet: Statsvetenskapliga institutionen:

Linsky, Martin; Jonathan Moore; Wendy O' Donnell \& David Whitman (1986) How the Press Affects Federal Policymaking. New York,London: W.W. Norton \& Company.

Larsson, Larsåke (1998) Nyheter i samspel. En studie om kommunjournalistikens villkor. Göteborgs universitet: JMG.

McLeod, Douglas M.; William P. Eveland \& Amy I. Nathanson (1997) Support for Censorship of Violent and Misogynic Rap Lyrics. An Analysis of the Third-Person Effect. Communication Research Vol. 24:153174.

Negrine, Ralph (1996) The Communication of Politics. London: Thousand Oaks, New Dehli: SAGE.

Neuwirth, Kurt; Edward Frederick \& Charles Mayo (2002) Person-Effects and Heuristic-Systematic Processing, Communication Research, Vol. 29:320-359.

Nord, Lars \& Jesper Strömbäck (2003). Valfeber och nyhetsfrossa-politisk kommunikation i valrörelsen 2002. Stockholm: Stiftelsen Institutet för Mediestudier.

Perloff, Robert M. (1993) Third-Person Effect Research 1983-1992: A Review and Synthesis, International Journal of Public Opinion Research Vol 5.

Perloff, Robert M. (1996) Perceptions and Conceptions of Political Media Impact: The Third-Person Effect and Beyond, in Crigler, Ann N. (ed) The Psychology of Political Communication. Ann Arbor: The University of Michigan Press.

Pierre, Jon \& Monica Djerf (1991) Massmedierna som omvärld: De kommunala beslutsfattarnas relationer till massmedierna, in Pierre, Jon (ed) Självstyrelse och omvärldsberoende: studier i lokal politik. Lund: Studentlitteratur.

Rucinski, D.M. \& Charles T. Salmon (1990) The "other" as the Vulnerable Voter. A Study of the Third-Person Effect in the 1988 U.S. Presidental Campaign, International Journal of Public Opinion Research Vol. 2:345-368.

Schudson, Michael (1995) The Power of News. Cambridge MA: Harvard University Press.

Strömbäck, Jesper (2000) Makt och medier. En bok om samspelet mellan medborgarna, medierna och de politiska makthavarna. Lund: Studentlitteratur. 
Strömbäck, Jesper (2001) Gäster hos verkligheten : en studie av journalistik, demokrati och politisk misstro. Eslöv: Bruno Östlings bokförlag. Symposion.

Swanson, David L. \& Paolo Mancini: (1997) Politics, Media and Modern Democracy: Introduction, i Swanson, David L \& Mancini, Paolo (ed.) Politics, Media and Modern Democracy. Westport, CT: Praeger Press.

Tiedge, James T.; Arthur Silverblatt; Michael J. Havice \& Richard Rosenfeld (1991) Discrepancy Between Perceived First-Person and Third-Person Mass Media Effects, Joumalism Quaterly Vol. 68.

Vallone, Robert P.; Lee Ross, \& Mark R. Lepper (1985) The Hostile Media Phenomenon: Biased Perceptions and Perception of Media Bias in Coverage of the Beirut Massacre, Journal of Personality and Social Psychology Vol. 49:577-588.

Weibull, Lennart (2001) The Swedish Media Landscape. Structure, Economy and Consumption. In Carlsson, U. \& Harrie, E. (eds.) Media Trends 2001 in Denmark, Finland, Norway and Sweden. Statistics and Analyses. Nordicom: Göteborgs universitet.

Whitt, H.P. (1983) Status Inconsistency: A Body of Negative Evidence or a Statistical Artifact? Social Forces, 62(1), 201-233.

Wrenne, Petter (1998) I skuggan av ett kommunalråd eller hur ett kommunalråd kan hamna $i$ skuggan. CEFOS: Göteborgs universitet.

This study was carried out within the research project Images of Media Power. Perceptions of Media Effects in Political Communication. The research project is financed by The Bank of Sweden Tercentenary Foundation. 


\section{Appendix}

\section{Sample}

The politician survey was carried out by the School of Public Administration at Göteborg University. It was sent to 943 persons. Of these, 38 were eliminated (no longer in service, deceased or on long-term sick leave). The net sample was therefore $943-38=905$. Of these, 675 responded to the survey, meaning a response rate of 74.6 percent. In the analysis the answers from the municipal politicians were not used but rather only the 496 regional politicians who filled in the survey.

The citizen survey was sent to 3,000 randomly selection persons between the age of 15 and 85 residing in Sweden. The postal survey has been carried out annually since 1986. The survey is sent is October-November each year. The SOM-survey includes questions about politics, social issues, public service, the mass media, the environment and numerous background questions. The response rate in the citizen survey is 69 percent. From the national sample was chosen those who lived in Region Västra Götaland, which was 310 persons. It is therefore possible to compare the views of the meaning of the media between elected officials and the general public in Region Västra Götaland.

\section{Effects of Mediated and Non-mediated Factors}

Respondents were asked two sets of questions about their perceptions of the influence of personal experience, interpersonal communication, television, newspapers and political advertising on the formation of political attitudes. In the first set the respondents were asked how these information-sources influenced their own political attitudes. The exact wording was:

\section{Sometimes it is discussed what influences our picture of politics. How important do you think these information channels are for your own political attitudes?}

In the second set of questions, respondents judged the perceived influence of the information sources on other people. The respondents answered the questions using a scale of 4 (very important) to 1 (very unimportant).

\section{First- and Third Person Effect}

To measure first- and third person perceptions, a "perceptual bias" transformation variable was created by computing the difference between each individual's other-scale and self-scale. Perceptual bias ranged from 3 ( 4 on others minus 1 on self) to -3 ( 1 on self minus 4 on others). Positive values indicated more effects on others, i.e. a third-person perceptual bias. Negative values indicate greater effects on one self, i.r. a firstperson perceptual bias or a first-person effect. A value of zero indicates no perceptual bias.

\section{Second Person Effect}

In recent studies of third person-effects, it has been suggested that a second person effect should be considered. It is a component of a "diamond model" developed by Whitt (1983) and recently adopted in third person effect research (Eveland et al.1999; McLeod et al. 1997, Neuwirth et al., 2002). Second person effect represents the perceived joint influence of the media on the self and others. A parallel, additive "self plus other" variable was therefore created which indicates this perceived joint influence of the information channels. The difference term in a regression represents a third- or a first person-effect, depending upon directing, controlling for the level of both (self and other) variables (Neuwirth et al., 2002).

Age

The untransformed age variable was used in the regression models, ranging between 24 and 79 years $(\mathrm{M}=54,6, \mathrm{sd}=9,38)$.

\section{Gender}

The gender variable was distributed as follows:

\begin{tabular}{lc} 
& Politicians \\
\hline Male & 280 \\
Female & 216 \\
\hline Total & 496 \\
\hline
\end{tabular}




\section{Length of Residence in the Community}

The respondents were asked about the length of residence in the community. For the politicians, the answers vary from less than one year to 75 years $(M=34,4, \mathrm{sd}=16,08)$.

\section{Education}

Education was measured by a question asking which level of education one had received. The responses were grouped into three categories: Low education (elementary school), middle high education (high school) and high education (college/ university).

\begin{tabular}{lc} 
& Politicians \\
\hline Low & 47 \\
Middle & 163 \\
High & 280 \\
No answer & 6 \\
\hline
\end{tabular}

\section{Political Experience}

In the survey the politicians were asked the number of political appointments they had at the time. Most politicians reported 1-3 political appointments, but exceptional cases mentioned as many as 19 political appointments.

\section{Job type}

Two of the appointments were County commissioner and Municipal commissioners. These appointments are full time employment. This position is central to local democracy in Sweden and they belong to limited informal networks of great importance to the local community. 95 of the 496 respondents reported that they had one of these political positions.

Paired T-tests Ranging the Information Channels Importance for the General Publics Political Attitudes (mean difference)

\section{Politicians}

\begin{tabular}{|c|c|c|c|c|c|}
\hline 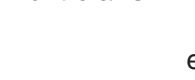 & $\begin{array}{c}\text { Personal } \\
\text { experience }\end{array}$ & $\begin{array}{l}\text { Interpersonal } \\
\text { communication }\end{array}$ & Television & Newspapers & $\begin{array}{c}\text { Political } \\
\text { advertising }\end{array}$ \\
\hline $\begin{array}{l}\text { Personal } \\
\text { experience }\end{array}$ & $x$ & 0,03 & 0,05 & $0,20 * * *$ & $0,80 * * *$ \\
\hline $\begin{array}{l}\text { Interpersonal } \\
\text { communicatio }\end{array}$ & & $\mathrm{X}$ & 0,02 & $0,17^{* * *}$ & $0,77^{* * *}$ \\
\hline Television & & & $X$ & $0,15^{* * *}$ & $0,76^{* * *}$ \\
\hline Newspapers & & & & X & 0,62 *** \\
\hline $\begin{array}{l}\text { Political } \\
\text { advertising }\end{array}$ & & & & & $x$ \\
\hline
\end{tabular}

Note: $*=\mathrm{p}<.10, * *=\mathrm{p}<.05, * * *=\mathrm{p}<.01$

\section{Citizens}

\begin{tabular}{|c|c|c|c|c|c|}
\hline & $\begin{array}{c}\text { Personal } \\
\text { experience }\end{array}$ & $\begin{array}{l}\text { Interpersonal } \\
\text { communication }\end{array}$ & Television & Newspapers & $\begin{array}{c}\text { Political } \\
\text { advertising }\end{array}$ \\
\hline $\begin{array}{l}\text { Personal } \\
\text { experience }\end{array}$ & $X$ & $0,10 * * *$ & $0,24^{* * *}$ & 0,10 *** & $0,86^{* * *}$ \\
\hline $\begin{array}{l}\text { Interpersonal } \\
\text { communicatio }\end{array}$ & & $\mathrm{X}$ & $0,13^{* * *}$ & 0,01 & $0,96 * * *$ \\
\hline Television & & & $\mathrm{X}$ & $0,14 * * *$ & $1,01 * * *$ \\
\hline Newspapers & & & & $\mathrm{X}$ & 0,96 *** \\
\hline $\begin{array}{l}\text { Political } \\
\text { advertising }\end{array}$ & & & & & $X$ \\
\hline
\end{tabular}

Note: $*=\mathrm{p}<.10, * *=\mathrm{p}<.05, * * *=\mathrm{p}<.01$ 